San Jose State University

SJSU ScholarWorks

Master's Theses

Master's Theses and Graduate Research

2005

\title{
Ergonomics training and office employees' attitude, awareness, and knowledge
}

Susan Tingley

San Jose State University

Follow this and additional works at: https://scholarworks.sjsu.edu/etd_theses

\section{Recommended Citation}

Tingley, Susan, "Ergonomics training and office employees' attitude, awareness, and knowledge" (2005). Master's Theses. 2790.

DOI: https://doi.org/10.31979/etd.4z7f-c4da

https://scholarworks.sjsu.edu/etd_theses/2790

This Thesis is brought to you for free and open access by the Master's Theses and Graduate Research at SJSU ScholarWorks. It has been accepted for inclusion in Master's Theses by an authorized administrator of SJSU ScholarWorks. For more information, please contact scholarworks@sjsu.edu. 


\title{
ERGONOMICS TRAINING AND OFFICE EMPLOYEES'
}

\author{
ATTITUDE, AWARENESS, AND KNOWLEDGE
}

\author{
A Thesis \\ Presented to \\ San Jose State University \\ In Partial Fulfillment \\ Of the Requirements for the Degree \\ Master of Science
}

The Faculty of the Department of Human Factors \& Ergonomics

By

Susan Tingley

August 2005 
UMI Number: 1429453

\section{INFORMATION TO USERS}

The quality of this reproduction is dependent upon the quality of the copy submitted. Broken or indistinct print, colored or poor quality illustrations and photographs, print bleed-through, substandard margins, and improper alignment can adversely affect reproduction.

In the unlikely event that the author did not send a complete manuscript and there are missing pages, these will be noted. Also, if unauthorized copyright material had to be removed, a note will indicate the deletion.

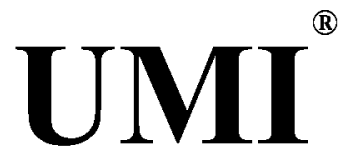

UMI Microform 1429453

Copyright 2006 by ProQuest Information and Learning Company. All rights reserved. This microform edition is protected against unauthorized copying under Title 17, United States Code.

ProQuest Information and Learning Company 300 North Zeeb Road

P.O. Box 1346

Ann Arbor, MI 48106-1346 
๑ 2005

Susan Tingley

ALL RIGHTS RESERVED 
APPROVED FOR THE GRADUATE PROGRAM
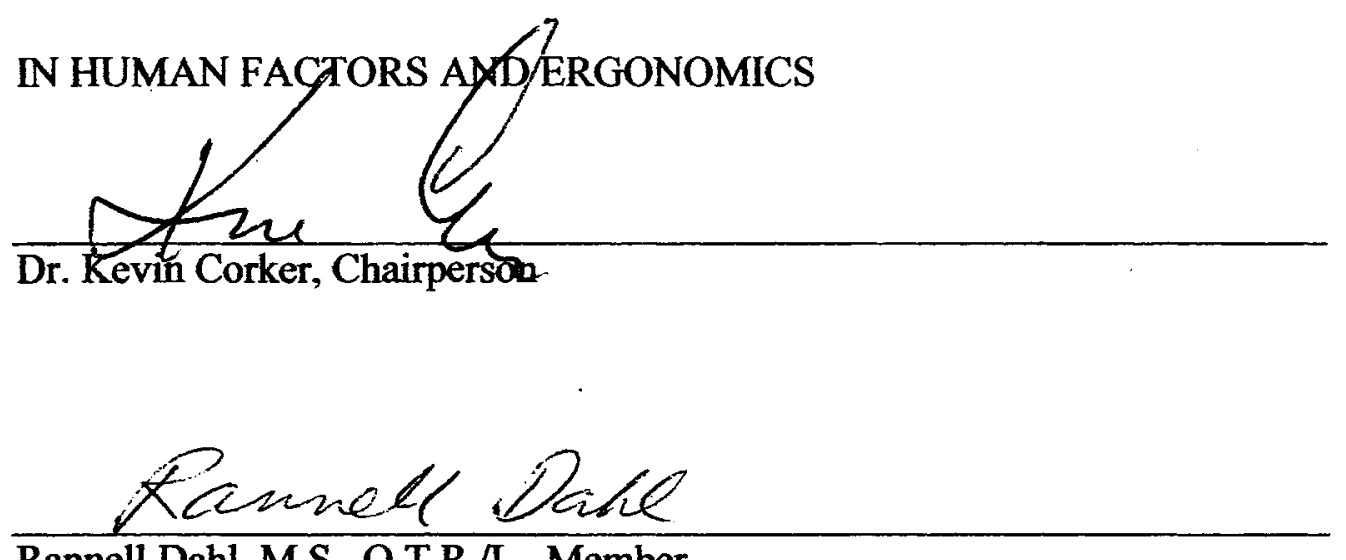

Rannell Dahl, M.S., O.T.R./L., Member

Fr. Fur

Dr. Fadi Fathallah, Member

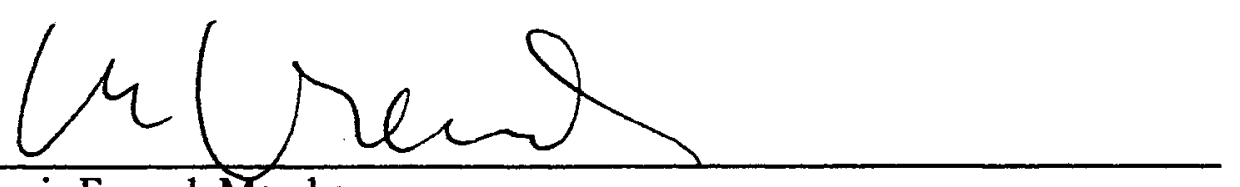

Dr. Louis Freund, Member

APPROVED FOR THE UNIVERSITY

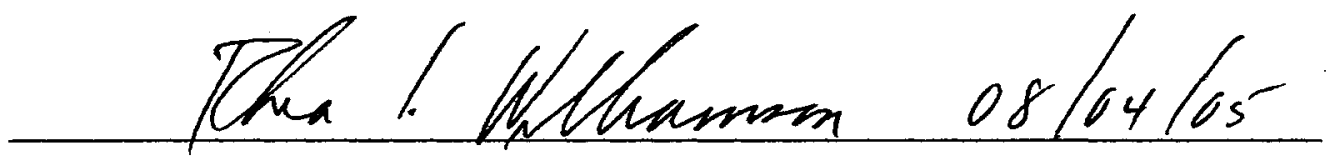




\author{
ABSTRACT \\ ERGONOMICS TRAINING AND OFFICE EMPLOYEES' \\ ATTITUDE, AWARENESS, AND KNOWLEDGE \\ By Susan Tingley
}

The purpose of this study is to evaluate the attitudes, perceived awareness levels, and ergonomic knowledge of office workers before and after training. Fifty-one participants who volunteered for this study were included. Twenty-eight $(55 \%)$ were non-symptomatic and $23(45 \%)$ were symptomatic. All persons with reports of workers' compensation claims were excluded. The provision of a 1-hour training class did result in significant improvements in attitude, perceived awareness, and knowledge regarding ergonomics. The presence of musculoskeletal symptoms did have a marginally significant effect on knowledge scores and had no effect on attitude or perceived awareness levels. This study demonstrates that office workers can benefit from training. Further investigation is needed to evaluate workers' application and retention of new ergonomic knowledge. 


\section{DEDICATION}

To my husband Walt, whose loving support and understanding is deeply

appreciated. To my friends Fran Wagner, Kristy Schultz, Ann Pudoff, and Rannell

Dahl, whose steady determination, encouragement, and support of me and each other make all the difference. Thank you. 


\section{TABLE OF CONTENTS}

LIST OF TABLES $\ldots \ldots \ldots \ldots \ldots \ldots \ldots \ldots \ldots \ldots \ldots \ldots \ldots \ldots \ldots \ldots \ldots \ldots$ viii

\section{Chapter}

$1 \quad$ INTRODUCTION $\ldots \ldots \ldots \ldots \ldots \ldots \ldots \ldots \ldots \ldots \ldots \ldots \ldots \ldots \ldots$

Purpose of Study $\ldots \ldots \ldots \ldots \ldots \ldots \ldots \ldots \ldots \ldots \ldots \ldots \ldots, \quad 3$

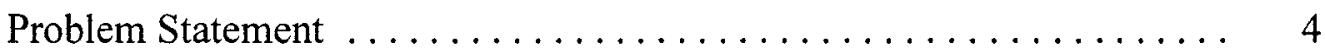

Significance of the Study $\ldots \ldots \ldots \ldots \ldots \ldots \ldots \ldots \ldots \ldots, 4$

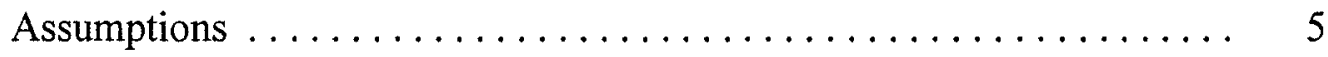

Constraints of this Study $\ldots \ldots \ldots \ldots \ldots \ldots \ldots \ldots \ldots \ldots \ldots$

Definition of Terms $\ldots \ldots \ldots \ldots \ldots \ldots \ldots \ldots \ldots \ldots \ldots$

2 LITERATURE REVIEW $\ldots \ldots \ldots \ldots \ldots \ldots \ldots \ldots \ldots \ldots \ldots$

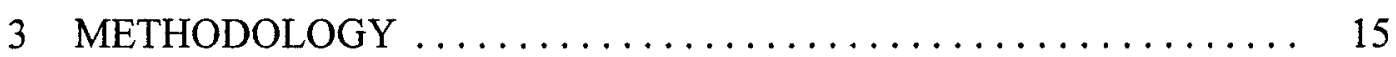

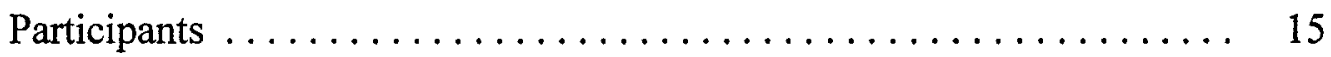

Apparatus or Instrumentation $\ldots \ldots \ldots \ldots \ldots \ldots \ldots \ldots \ldots \ldots, 16$

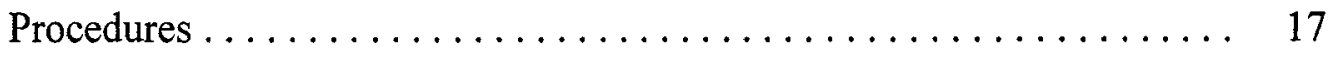

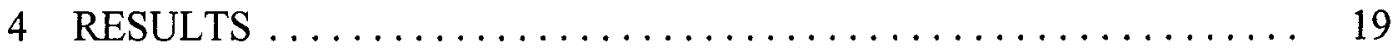

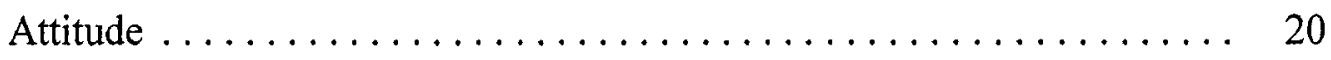

Awareness ................................. 24

Knowledge $\ldots \ldots \ldots \ldots \ldots \ldots \ldots \ldots \ldots \ldots \ldots \ldots \ldots, 27$

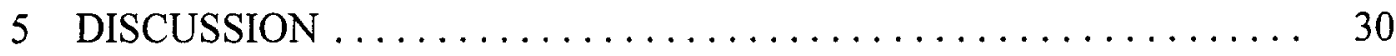


REFERENCES $\ldots \ldots \ldots \ldots \ldots \ldots \ldots \ldots \ldots \ldots \ldots \ldots \ldots \ldots \ldots \ldots \ldots$

APPENDICES

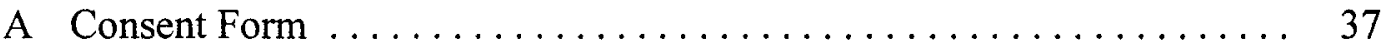

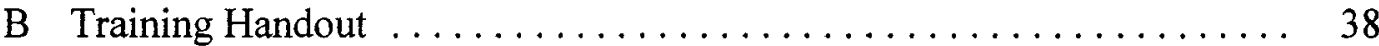

C Pre-Training Assessment $\ldots \ldots \ldots \ldots \ldots \ldots \ldots \ldots \ldots \ldots \ldots \ldots$

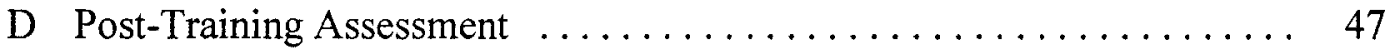

E Demographic Survey $\ldots \ldots \ldots \ldots \ldots \ldots \ldots \ldots \ldots \ldots \ldots \ldots$ 


\section{LIST OF TABLES}

Table

1 Responses for Attitude about Belief in Preventing Injury Within Subjects (A) and Between Subjects (B) $\ldots \ldots \ldots 21$

2 Responses to Question \#1: Do you believe that you can prevent an injury by changing the way you work? . . . . . . 21

3 Responses for Attitude of Willingness to Change the Way to Work Within Subjects (A) and Between Subjects (B) ....... 23

4 Responses to Question \#2: Are you willing to change the way you work? ...................... 23

5 Mean Ranking of Perceived Awareness of Workstation or Chair Adjustment and Work Techniques ............. 25

6 Ranking of Awareness for Adjustment of the Chair or Workstation Within Subjects (A) and Between Subjects (B) ..... 26

7 Ranking of Perceived Awareness for Work Technique

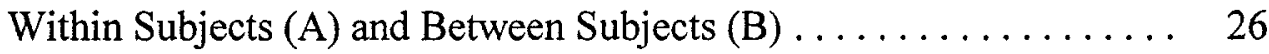

8 Knowledge Scores (percentage correct) Within Subjects (A)

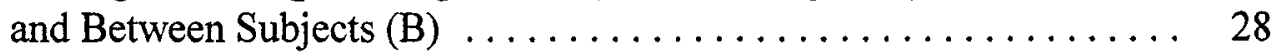

9 Mean Knowledge Scores and Corresponding Percentage Correct . . . . . 28 


\section{Chapter 1}

\section{INTRODUCTION}

Musculoskeletal problems result in the average employed person losing nearly two days of work each year, and during the working years (ages 18-64) more people are disabled from musculoskeletal problems than from any other category of disorder (Putz-Anderson, 1988). Musculoskeletal disorders (MSDs) are defined by the Bureau of Labor Statistics as an injury or disorder of the muscles, nerves, tendons, joints, cartilage, and spinal discs that do not include disorders caused by slips, trips, falls, motor vehicle accidents, or similar accidents. In 2001, 25\% of the MSD injuries/ illnesses were related to the worker motion or position (Bureau of Labor Statistics [BLS], 2001). The National Institute for Occupational Safety and Health [NIOSH] (1997) performed a critical review of the epidemiologic literature and identified a number of specific physical exposures strongly associated with specific musculoskeletal disorders when exposures are intense, prolonged, and particularly when workers are exposed to several risk factors simultaneously. Lindell (1994) states that situations of exposure to chronic hazards make it impossible to learn from trial and error because the years or decades it takes to produce these delayed effects eliminates the opportunity for individuals to draw accurate conclusions from their experience. Additionally, Lindell describes the importance of workers acquiring positive attitudes and learning why to follow the safe procedures recommended by trainers instead of practicing unsafe actions. Thus, health and safety training must encourage positive 
attitudes as well as increase awareness and knowledge of methods to minimize prolonged exposures that increase the likelihood of developing MSDs.

The purpose of this study is to evaluate the attitudes, perceived awareness levels, and ergonomic knowledge of workers with and without musculoskeletal symptoms, before and after a training class. Townsend (1998) describes ergonomics as preventative and as loss control, not curative nor clinical treatment. Townsend states that the effectiveness of an ergonomics program relies on a combination of four areas: Training, workstation analysis, hazard prevention and control, and medical management. He further states that ergonomics training, combined with ergonomically sound workstations, helps supervisors and employees leärn and apply safety strategies and workstation adjustments. Although, he cautions that training can be misused as a way to shift responsibility for ergonomics from management to computer users or as a way to avoid modernizing the workplace. Training must receive consistent support and be reinforced at all levels of the organization to have a long-term impact. Ergonomics training programs should be action-oriented and lead to employee involvement. Additionally, ergonomics training should include background information on the risk factors related to cumulative trauma injuries, the overall work performed at the workstations, as well as the computer workstation design and adjustment principles.

While an ergonomics program is multi-faceted, this particular study is limited to the area of training. Many factors, including attitude, motivation, and information 
provided, can affect the success of training that is part of an ergonomics program. Attitudes must change before behavior can change, as indicated by the six-stage model described by Urlings, Nijboer, and Dul (1990). The stages include giving attention to information, understanding information, changing attitudes, changing intentions, changing behavior, and maintaining new behavior. Lindell (1994) states that when the recommended protective action is perceived to be effective, the motivation aroused by the description is directed toward consistently abiding by the recommended safety practices. Additionally, an individual will have an increased likelihood of engaging in safe behaviors to the extent that an individual is given very specific information regarding potential accidents along with clear means of averting these accidents.

\section{Purpose of Study}

The purpose of this study is to measure attitude, perceived awareness levels, and knowledge of basic ergonomic principles and guidelines in office workers before and after a training class. The relationship of people's attitudes, perceived awareness levels, demonstrated knowledge, and reports of musculoskeletal symptoms will be evaluated. Employers and health and safety trainers can utilize the information gathered from this study as a basis for the development and implementation of classroom-style educational training for office workers that can be utilized as part of an overall ergonomics program. Specifically, this study will determine:

1. The impact of ergonomics training on employees' attitudes about their ability to minimize the individual risk for the development of a musculoskeletal disorder 
and their willingness to change the way they work. In this study, attitude refers to the participants' belief that an injury can be prevented by changing the way they. work and by participants' willingness to change the way they work.

2. The impact of ergonomics training on the employees' perceptions of their awareness to adjust the chair or workstation and work technique. Adjusting the chair or workstation refers to the mechanical positioning of the chair or workstation components such as the keyboard or monitor heights. Adjusting the work techniques refers to the body mechanics of the participants such as typing techniques and individual posture.

3. The efficacy of ergonomics training on the employees' knowledge of ergonomics principles that apply to an office worker.

\section{Problem Statement}

This study will determine if a training class is effective in improving office workers' attitudes, perceived awareness level, and knowledge about basic ergonomics principles and guidelines.

\section{Significance of the Study}

Musculoskeletal disorders are costly to both employers and employees. Musculoskeletal disorders (MSDs) account for one-third of all Workers' Compensation costs for medical care and lost wages (California Department of Industrial Relations [DIR], 2000; Faucett, Garry, Nadler, \& Ettare, 2002). Stahl (1997) describes the cost to the worker as including the loss of physical capacity, 
income, job opportunities, and an overall loss of acquired lifestyle. In response to the high cost of musculoskeletal disorders, ergonomics programs are becoming more prevalent. Additionally, general information regarding office ergonomics is more readily available to the general public though Internet access. It is possible that a general high level of knowledge among office workers for basic ergonomics principles already exists. Therefore, it is hypothesized that a 1-hour ergonomics training class will not have a significant impact on office workers' attitude, perceived awareness levels, or knowledge of ergonomics principles.

\section{Assumptions}

The volunteer participants were recruited by email that described the training course as covering basic ergonomic and injury prevention principles that are applicable to office situations. It is assumed that all the workers in this study perform common office job tasks such as computer work, as opposed to non-office job tasks such as manual material handling. The surveys completed by the participants were anonymous. Therefore, it is assumed that the participants honestly answered whether they had filed a workers' compensation claim in the past or whether they had musculoskeletal symptoms.

\section{Constraints of this Study}

The study is limited to employees of the California State Department of Health Services located in Sacramento. Employees with workers' compensation claims were excluded from this study. Participants were divided into two groups: Office 
employees with reports of musculoskeletal disorders, and office employees without reports of musculoskeletal disorders on the pre-training assessment.

\section{Definition of Terms}

Attitude. Attitude is an individual's feeling or emotion (Merriam-Webster Dictionary Online, 2002).

Behavior. Organizational, management, or worker performance (Johnston, Cattledge, \& Collins, 1994).

Ergonomics. The application of scientific information concerning humans to the design of objects (e.g., tools), systems (e.g., job process), and environment (e.g., indoor or outdoor) for human use (Ergonomics Society, 1996). It is fitting the task (i.e., work or job) to the worker (i.e., human) (Kroemer \& Grandjean, 1997).

Knowledge. Safety information (Johnston et al., 1994).

Musculoskeletal Disorders. Musculoskeletal disorders are classified as an "... illness due to repeated trauma. It is an illness to the muscles, ligaments, tendons, bones, or nerves that develops over a period of time" (BLS, 2001, n.p.).

Training. Formal or informal methods to assist individuals in acquiring knowledge, changing attitudes, or executing safe work behaviors (Johnston et al., 1994).

Research in the field of ergonomics training was reviewed. The role of attitude, awareness, and knowledge were identified as important factors related to ergonomics training and are used as the basis for hypothesis statements in this study. 


\section{Chapter 2}

\section{LITERATURE REVIEW}

Approximately three-quarters of a million work-related injuries and illnesses are reported in California every year (Commission on Health \& Safety and Workers' Compensation [CHSWC], 2003). Evidence suggests that many work-related illnesses go unreported. Morse, Dillon, Warren, Levenstein, and Warren (1998) performed a telephone survey and found that only $10.6 \%$ of persons reporting significant upper quadrant pain for 5 or more consecutive days, or 20 or more total days in the preceding year, that was not due to sudden injury, had filed a workers' compensation claim. The remaining $89.4 \%$ had not filed a workers' compensation claim. A statewide survey in Michigan reported that only $25 \%$ of workers with known or suspected repetitive trauma disorders of the wrist, shoulder, or back had filed for workers' compensation (Rosenmann et al., 2000). Silverstein, Stetson, Keyserling, and Fine (1997) found substantial underreporting of work-related musculoskeletal disorders when comparing health surveillance interviews and physical examinations to reporting on OSHA logs. Another study of work-related injuries by Morse, Dillon, Warren, Hall, and Hovey (2001) estimates unreported cases exceed those officially reported by a factor of 11:1 in Connecticut. Morse et al. go on to state that if unreported musculoskeletal disorders are not taken into account, then employers will not easily be able to measure the cost effectiveness of safety measures. 
McCunney (2001) describes that the provision of a physical environment conducive to productivity, along with the establishment of systems for early recognition of and responses to work-related illnesses and injuries, provide further support for productive activity. According to the World Health Organization [WHO] (1999), healthier populations tend to have higher labor productivity because the workers are more physically energetic and mentally more robust. Thus, it can be surmised that effective ergonomics programs will potentially reduce the number of workers' compensation claims and also potentially increase productivity by improving the comfort levels of workers without reported injuries.

An ergonomics program is likely to have more success in encouraging people to accept change if the beliefs, attitudes, and knowledge of the individuals and the organization are taken into account when implementing ergonomics (Haslam, 2002). An employer's commitment to safety should not only provide information, but also encourage positive beliefs and attitudes of workers and management to lead to a successful implementation and maintenance of an ergonomics program. The National Institute for Occupational Safety and Health [NIOSH] (1997) recommends policy statements that treat ergonomic efforts as furthering the company's goals of maintaining and preserving a safe and healthful work environment for all employees; expect full cooperation of the total work force in working together toward realizing ergonomic improvements; assign lead roles to designated persons who know how to "make things happen"; give ergonomic efforts priority with other cost reduction, 
productivity, and quality assurance activities; and have the support of the local union or other worker representatives. Additionally, NIOSH suggests goals be set that are concrete and give priority to the jobs posing the greatest risk, and that resources be committed to training the workforce and providing detailed instructions and bringing in outside experts until in-house expertise can be developed.

Involving people in the analysis, development, and implementation of ergonomics, often referred to as "participatory ergonomics," builds ownership and commitment to the solutions for improvement (Haines, Wilson, Vink, \& Kaningsveld, 2002).

A participatory ergonomics program aimed at management of occupational back pain was evaluated by Loisel et al. (2001). A trained employer representative was utilized to meet with the ergonomist to review and, if needed, reconcile the job task descriptions, identify the tasks associated with back pain risk factors, describe the back accidents, describe the workplace characteristics, and identify work organization and job demands related to risks for the back. The injured worker and the ergonomist observed and evaluated the usual work tasks being performed by another worker and together drafted a report with suggestions for work improvement. The last step involved the injured worker, the trained representative, the supervisor, and the ergonomist meeting to reach a consensus on the job tasks needing improvement, to develop solutions, to evaluate the feasibility and priority of these solutions, and to set a timetable and person(s) responsible for overseeing the follow-up. Out of 226 
ergonomic solutions for job task improvements, 123 solutions targeted posture. Approximately half of all the solutions proposed were implemented. Reasons for partial or non-implementation of solutions were identified as disruption of work procedures, modification of the injured worker's job type, technical difficulties, work conflicts, costs, company reorientation, limited company resources, influence on other job sites, and other reasons. The potential impact of changes on company work methods outweighed the costs as the major reason for partial or non-implementation of solutions.

This suggests that a thorough understanding of work conditions is necessary for implementing ergonomics. Employees have a better understanding of work methods and work conditions than an outside person. Thus, training employees in ergonomics principles is necessary to develop ergonomics solutions that are feasible in the work place setting. Menozzi et al. (1999) explain that training of personnel can lead to an increase in self-responsibility, which consequently leads to better workplace conditions, as trained employees can assess the ergonomics at their own workplace, establish and carry out changes, and maintain optimal conditions.

Training efficiency, the greatest level of proficiency per dollar invested, is defined by what method of training provides the best learning in the shortest time, leads to the longest retention, and is least expensive (Wickens, 1992). What is considered the "best learning" for a specific work setting can be difficult to define 
and quantify. Learning implies the acquisition of knowledge. However, in the real-world setting, it is the ability to apply that knowledge that is important.

Schurman, Silverstein, and Richards (1994) describe that knowledge is constructed as the result of peoples' efforts to understand and influence their situation. Although outside experts may have more technical health and safety or social systems knowledge, insiders have more expertise about their work activities and work processes. Teaching/learning transactions need to be built around opportunities for direct participation by the workers in altering the conditions in the workers' immediate source of health and safety problems.

Lecture style training is one avenue for providing employees the technical health and safety knowledge needed to change their work setting. Lecture can be an effective teaching method when used with participant discussion, according to Rankin and Stallings (1996). Lecture can be enhanced with handouts, pictures, and visual aids that the participants can relate to. Successful training will have material that is at the learners' level of understanding, will provide participants the opportunity to ask questions, will be an appropriate length without being "too lengthy," and will allow the learners the opportunity to apply their new knowledge of skills.

There are many outcome measures that have been utilized in an attempt to measure the acquisition of knowledge through training as well as the effectiveness of training in changing attitude and behavior. Outcome measures may include absenteeism and incidence of injury (Versloot, Rozeman, Van Soon, \& Van 
Akkerveeken, 1992); physical measures of disability and educational compliance (DeFabio, 1995); or time off work, number and duration of recurrences, and physical examination results (LeClaire et al., 1996). The presence of musculoskeletal symptoms is the most common health outcome to be used (NIOSH, 1997).

Bohr (2000) utilized outcome measures of participants' self-report of pain/ discomfort and psychosocial work aspects, and an observer's report of work area configuration and work postures in his investigation of the efficacy of worker education programs in preventing musculoskeletal injuries in computer users at a reservation center. Three groups were compared: A control group, a traditional education intervention group, and a participatory education group. The traditional education intervention consisted of a 1-hour lecture with informational handouts. The participatory education intervention lasted 2 hours and consisted of hands-on demonstration and a problem-solving approach with the use of case studies followed by the participants working in pairs to evaluate and modify their work areas. Modifications were made under the supervision of the instructor. Data collected included surveys completed by the participants and observational checklists completed by the researcher at baseline (before the intervention) and at approximately 3,6 , and 12 months post-intervention. The study provides some evidence that worker education did have an impact on the workers' perception of their health status, the frequency of pain/discomfort related work activities, and the level of psychosocial stress as both educational groups showed a significant decrease in the pain/discomfort and 
psychosocial data analysis. However, there was not a significant difference between the two educational groups, indicating that the traditional education was not more or less effective than the participatory education. Interestingly, changes in work area configuration and worker postures were not detected in this study. This may be due to administrative restructuring that occurred during the study period that resulted in some workers who changed work areas, sometimes during a single shift, and thus may have decreased the workers' motivation to readjust the work area at each change.

Generally, the goal of training is that workers have acquired the appropriate knowledge, attitude, and skills to perform their jobs safely. Workers' safe performances of their jobs are affected by their opportunities and motivation to apply what they have learned in training (Baldwin \& Ford, 1988). The opportunity to apply what has been learned must exist. As with other safety programs, training is only one piece of a successful safety program. The appropriate attitude, knowledge base, equipment, tools, and work processes must be in place to allow for safe work to be performed.

It is expected that employees will believe that they can prevent an injury and will be willing to change the way in which they work to prevent an injury. Additionally, as ergonomic programs have become more common in the work place, it is expected that employees will perceive themselves to have awareness of workstation or chair adjustments and work technique and, furthermore, be able to demonstrate that they do have knowledge of general ergonomics principles and guidelines. 
The following hypotheses will be tested in this study.

1. There is no relationship between ergonomics training and employees' attitude of their ability to minimize risk for musculoskeletal disorders.

2. There is no relationship between ergonomics training and employees' willingness to change the way they work to minimize risk for musculoskeletal disorders.

3. There is no relationship between ergonomics training and employees' perception of their awareness level in ways to adjust the chair or workstation.

4. There is no relationship between ergonomics training and employees' perception of their awareness in ways to change work techniques.

5. There is no relationship between ergonomics training and demonstrated level of employee's knowledge of general office ergonomics principles and guidelines. 


\section{Chapter 3}

\section{METHODOLOGY}

The purpose of this study is to evaluate office workers' attitudes, perceived awareness levels, and knowledge of office ergonomic principles and guidelines before and after an ergonomics training class. Employees with a report of workers' compensation claims were excluded from this study.

1. A pre-training assessment measures overall attitude, perceived awareness level, and knowledge of office ergonomic principles and guidelines among office workers with and without reports of musculoskeletal disorders.

2. A post-training assessment measures overall attitude, perceived awareness level, and knowledge of office ergonomic principles and guidelines among office workers with and without reports of musculoskeletal disorders.

\section{Participants}

A Unit Manager from the California Department of Health Services emailed employees located in Sacramento an announcement of the training class and this study. Employees were allowed to attend the training whether they chose to participate in the study or not. The employees who participated in the study were volunteers and did not receive any compensation. The maximum population was set at 200 as this was the maximum number of participants that the Department could provide at one time and the maximum number of people that could be seated in the auditorium wherein 
the training was held. Since the sample was voluntary, it was anticipated that some participants would have no reports of musculoskeletal disorders, some participants would have reports of musculoskeletal disorders but no workers' compensation claims, and some participants would have reports of musculoskeletal disorders and a workers' compensation claim. Persons with a workers' compensation claim were excluded from this study. This means that each of the participants included in this study would fall into one of the following categories: (a) Non-symptomatic worker or (b) symptomatic worker who did not file a workers' compensation claim.

\section{Apparatus or Instrumentation}

To measure the participants' attitude, perceived awareness level, and knowledge of office ergonomic principles and guidelines, training was provided and pre- and post-training assessments were administered. Since all participants attended the same training class, all participants received the same information in the training. Prior to the training, participants completed a pre-training assessment that measured attitude, perceived awareness level, and knowledge of office ergonomic principles and guidelines. Upon completion of the training, the same assessment was administered to measure any change in attitude, perceived awareness level, and knowledge.

At the time of the post-training assessment, participants were also asked to complete a demographic survey that identified employee characteristics such as gender and age; as well as non-symptomatic workers, symptomatic workers, and workers with 
a worker's compensation claim. The survey was completed after the training, as it contained information and terminology that was covered in the training.

Each participant was issued a packet of handouts to follow during the training. Each packet was identified with a number, ranging between 1 and 200 . Each participant was asked to write his or her identification number on the pre-training assessment, post-training assessment, and the demographic questionnaire. To assure anonymity, at no time were names collected or associated with identification numbers. The purpose of the study was explained to the participants, and they were asked to cooperate fully by responding to the assessments' questions openly and honestly.

\section{Procedures}

Subjects were asked to provide their consent to participate in this study (Appendix A) prior to taking the pre-training assessment immediately before training. They were advised of the purpose of the study and that their responses would remain anonymous. They were advised that they could stay for the training whether they chose to participate in the study or not. The handouts (Appendix B) were numbered 1 through 200 and were distributed. Participants were provided with handouts that were used in conjunction with the training, and they were instructed to record their identification number on the first page of their pre-training assessment (Appendix C). Participants were instructed to complete the pre-training assessments, and to direct any questions to the instructors. Participants completed the pre-training assessments and 
turned them in to the instructors. All pre-training assessments were accounted for before the training began.

One-hour training was provided by two instructors. The training covered basic office ergonomic guidelines and principles, including:

- Introduction to ergonomics

- Musculoskeletal Disorders (MSDs)

Definitions

Causes

Symptoms

- $\quad$ Risk factors for MSDs

- Control strategies for preventing MSDs

- Photo analysis

- Adjusting the computer workstation--making it fit

- Questions and answers/discussion

After the training, the post-training assessment (Appendix D) and the demographic survey (Appendix E) were distributed. Participants were instructed to write their identification numbers on each of these documents before completing them. When completing the post-training assessment, they were allowed to refer to the training handouts. Participants were instructed to direct their questions to the instructors. 


\section{Chapter 4}

\section{RESULTS}

The purpose of this study is to measure attitude, awareness, and knowledge of basic ergonomic principles and guidelines among office workers. The dependent variables are participants' perceptions of their attitudes and awareness and the participants' knowledge. "Attitude" refers to the participants' beliefs that they can prevent injuries by changing the way they work, and their willingness to change the way they work. "Awareness" refers to participants" perception of their awareness of ways to adjust the chair or the workstation, and to perform safe working techniques. "Knowledge" refers to the participants' understanding of basic ergonomic guidelines and principles by responding to a set of questions in pre- and post-training assessments. The independent variable in this study is the training class.

Participants who reported having a workers' compensation claim were excluded from this study. The population of this study consisted of two groups: (a) Non-symptomatic--those who reported having no musculoskeletal disorders (MSDs) on a demographic survey, and (b) Symptomatic--those who reported having a musculoskeletal disorder on a demographic survey. A total of 51 participants completed the entire study and did not report having a worker's compensation claim. Nine other participants reported having a workers' compensation claim on the demographic survey and were not considered in the analysis of this data. 
A total of 28 out of 51 (55\%) participants were non-symptomatic participants who reported no musculoskeletal disorders. A total of 23 out of 51 (45\%) participants were symptomatic participants who reported musculoskeletal disorders, but had not filed workers' compensation claims. The average age of the participants included in this study was 51 years. Thirty-six (71\%) were females and $15(29 \%)$ were males.

\section{Attitude}

To measure attitude, participants were asked to answer "Yes," "No," or "Maybe" to the following questions on the pre- and post-training assessments: 1. Do you believe that you can prevent an injury by changing the way you work? 2. Are you willing to change the way you work?

A two-way ANOVA was calculated on Question \#1 regarding belief in prevention of injury (Table 1). The results of the two-way ANOVA on the within subjects pre-test/post-test responses are significant $(p=.037)$, but the between subjects presence of musculoskeletal symptoms did not have any significant main effects.

In response to Question \#1 on the pre-training assessment (Table 2), a total of 42 out of the $51(82.4 \%)$ participants answered Yes. Twenty four of the participants who responded Yes were non-symptomatic and 18 were symptomatic. A total of eight of the participants (15.6\%) answered Maybe. Three of the participants who answered Maybe were non-symptomatic and five were symptomatic. One participant (2\%) answered No. This participant was non-symptomatic. 
Table 1

Responses for Attitude about Belief in Preventing Injury Within Subjects (A) and Between Subjects (B)

\begin{tabular}{llllll}
\hline \multicolumn{1}{c}{ Source } & SS & DF & MS & F & Significance \\
\hline Pre/Post training (A) & 0.118 & 1 & 0.118 & 4.604 & $.037^{*}$ \\
NS/S (B) & 0.0128 & 1 & 0.0128 & 0.322 & .573 \\
A x B & 0.00024 & 1 & 0.00024 & 0.010 & .923 \\
$\quad$ & & 50 & & & \\
\hline
\end{tabular}

Note. NS = non-symptomatic participants; $\mathrm{S}=$ symptomatic participants ${ }^{\star} p<.05$

Table 2

Responses to Question \#1: Do you believe that you can prevent an injury by changing the way you work?
Non-symptomatic ${ }^{\mathbf{a}}$
Symptomatic ${ }^{\mathrm{b}}$
Total

\begin{tabular}{llllllllllll} 
Assessment & Yes & Maybe & No & Yes & Maybe & No & Yes & Maybe & No \\
Pre-training & 24 & 3 & 1 & 18 & 5 & 0 & 42 & 8 & 1 \\
Post-training & 27 & 1 & 0 & 21 & 2 & 0 & 48 & 3 & 0 \\
\hline
\end{tabular}

$a_{n}=28 ; b_{n}=23$ 
After the training class in response to Question \#1 on the post-training assessment, the total number of participants who answered Yes increased to 48 out of $51(94 \%)$. Twenty-seven of the participants who answered Yes were non-symptomatic and 21 were symptomatic. The total number of participants who answered Maybe decreased to three participants (6\%). One participant who answered Maybe was non-symptomatic and two were symptomatic. None of the participants answered No to this question on the post-training assessment.

A two-way ANOVA was calculated on Question \#2 regarding the participants' willingness to change the way they worked (Table 3). The results of the two-way ANOVA on the within subject pre-test/post-test responses are significant $(p=.032)$, but the between subject presence of musculoskeletal symptoms did not have any significant main effects.

In response to Question \#2 "Are you willing to change the way you work?" on the pre-training assessment (Table 4$), 46$ out of the $51(90.2 \%)$ participants answered Yes. Twenty-four of the participants who answered Yes were non-symptomatic and 22 were symptomatic. Five participants $(9.8 \%)$ answered Maybe. Four of the participants who answered Maybe were non-symptomatic and one was symptomatic. None of the participants answered No to this question on the pre-training assessment. After the training class, in response to Question \#2 on the post-training assessment, the total number of participants who answered Yes increased to 51 out of $51(100 \%)$ participants. 
Table 3

Responses for Attitude of Willingness to Change the Way to Work Within Subjects (A) and Between Subjects (B)

\begin{tabular}{llllll}
\hline \multicolumn{1}{c}{ Source } & SS & DF & MS & F & Significance \\
\hline Pre/Post training (A) & 0.0548 & 1 & 0.0548 & 4.899 & $.032^{\star}$ \\
NS/S (B) & 0.01559 & 1 & 0.01559 & 1.394 & .244 \\
A x B & 0.01559 & 1 & 0.01559 & 1.394 & .244 \\
$\quad$ & & 50 & & & \\
\hline
\end{tabular}

Note. $\mathrm{NS}=$ non-symptomatic participants; $\mathrm{S}=$ symptomatic participants ${ }^{*} p<.05$

Table 4

Responses to Question \#2: Are you willing to change the way you work?

\begin{tabular}{lcccccccccc}
\hline & \multicolumn{1}{c}{ Non-symptomatic $^{\mathrm{a}}$} & \multicolumn{2}{c}{ Symptomatic $^{\mathrm{b}}$} & \multicolumn{2}{c}{ Total } \\
\hline Assessment & Yes & Maybe & No & Yes & Maybe & No & Yes & Maybe & No \\
\hline Pre-training & 24 & 4 & 0 & 22 & 1 & 0 & 46 & 5 & 0 \\
Post-training & 28 & 0 & 0 & 23 & 0 & 0 & 51 & 0 & 0 \\
\hline${ }^{n} n=28 ;{ }^{b}=23$ & & & & & & & & &
\end{tabular}




\section{Awareness}

To measure awareness, participants were asked to rank their perceptions of their awareness of chair or workstation adjustments and work technique on a five-step Likert scale. The questions were numbers 3 and 4 on the pre- and post-training assessments:

3. Are you aware of ways to adjust your chair or workstation to make it safer?

4. Are you aware of ways to change your work technique to make it safer?

Before the training class in response to Question \#3 "Are you aware of ways to adjust your chair or workstation?" for all the participants the average score was 3.58 on a 5-step Likert scale (Table 5). The non-symptomatic participants' avërage score was 3.43 and the symptomatic participants' average score was 3.26. After the training class in response to Question \#3, for all participants the average score increased to 4.14 on the 5 -step Likert scale. The non-symptomatic participants' average score increased to 4.25 and the symptomatic participants' average score increased to 4.0.

Before the training class in response to Question \#4 "Are you aware of ways to change your work technique to make it safer?" for all the participants the average score was 3.0 on a 5-step Likert scale. The non-symptomatic participants' average score was 3.07 and the symptomatic participants' average score was 2.91 . After the training class in response to Question \#4, for all the participants the average score was 4.16 on a 5 -step Likert scale. The non-symptomatic participants' average score was 4.14 and the symptomatic participants' average scores was 4.17 . 
Table 5

Mean Ranking of Perceived Awareness of Workstation or Chair Adjustment and Work Techniques

\begin{tabular}{lcccccc}
\hline & \multicolumn{2}{c}{ Non-symptomatic } & \multicolumn{2}{c}{ Symptomatic $^{\mathrm{b}}$} & \multicolumn{2}{c}{ Total } \\
\cline { 2 - 7 } Assessment & WS/Chair & Technique & WS/Chair & Technique & WS/Chair Technique \\
\hline Pre-training & 3.43 & 3.07 & 3.26 & 2.91 & 3.58 & 3.0 \\
Post-training & 4.25 & 4.14 & 4.0 & 4.17 & 4.14 & 4.16 \\
\hline
\end{tabular}

Note. Ranking based on 5-step Likert scale. WS/Chair $=$ workstation or chair awareness. ${ }^{a} \mathrm{n}=28 ;{ }^{b} \mathrm{n}=23$

A two-way ANOVA was calculated to determine if there was a difference within groups and between groups when participants were asked about their awareness of chair and workstation adjustments (Table 6). The results of the two-way ANOVA on the within subject pre-test/post-test responses are significant $(p<.01)$, but the between subject presence of musculoskeletal symptoms did not have any significant main effects.

A two-way ANOVA was calculated to determine if there was a difference within groups and between groups when participants were asked about their awareness of work techniques (Table 7). The results of the two-way ANOVA on the within subject pre-test/post-test responses are significant $(\mathrm{p}<.01)$, but the between subject presence of musculoskeletal symptoms did not have any significant main effects. 
Table 6

Ranking of Awareness for Adjustment of the Chair or Workstation Within

Subjects (A) and Between Subjects (B)

\begin{tabular}{lccccc}
\hline & SS & DF & MS & F & Significance \\
\hline Pre/Post training (A) & 15.376 & 1 & 15.376 & 27.628 & $.000^{\star}$ \\
NS/S (B) & 1.102 & 1 & 1.102 & 0.717 & .401 \\
A x B & 0.04276 & 1 & 0.04276 & 0.077 & 7.83 \\
$\quad$ & & 50 & & & \\
\hline
\end{tabular}

Note. NS = non-symptomatic participants; $\mathbf{S}=$ symptomatic participants $\star_{p}<.01$

Table 7

Ranking of Perceived Awareness for Work Technique Within Subjects (A) and Between Subjects (B)

\begin{tabular}{lccccc}
\hline & SS & DF & MS & F & Significance \\
\hline Pre/Post training (A) & 34.344 & 1 & 34.344 & 54.032 & .000 * \\
NS/S (B) & 0.102 & 1 & 0.102 & 0.077 & 7.83 \\
A x B & 0.227 & 1 & 0.356 & .553 & 7.83 \\
$\quad$ Total & & 50 & & & \\
\hline
\end{tabular}

Note. NS = non-symptomatic participants; $\mathbf{S}=$ symptomatic participants ${ }^{*} p<.05$ 


\section{Knowledge}

Pre- and post-training assessments measured participants' knowledge of basic ergonomic principles and guidelines, before and after training. For each of 15 questions, participants were asked to select the best answer from a list of four choices. For example, "What is the guideline for keyboard height?" (a) It should be slightly higher than my elbows, (b) It should be at or slightly below my elbows, (c) It should be 29"-30" above the floor, (d) I don't know. The questions on the pre- and post- training assessments were identical.

For all participants who completed pre- and post-training assessments and had not filed a workers compensation claim (Table 8), the group's average pre-training assessment score was 6.84 out of a total of $15(45.62 \%)$ correct. The group's average post-training assessment score was 12.65 out of a total of $15(84.31 \%)$ correct. This represents a significant difference $(p<.01)$ between pre- and post-training assessment scores. The difference between non-symptomatic and symptomatic knowledge scores was very marginally significant because it is close to 0.05 and less than 0.1 .

The non-symptomatic group's average pre-training assessment score was 6.36 out of $15(42.4 \%)$ compared to the post-training assessment score of 12.25 out of $15(81.66 \%)$. For the symptomatic participants, the average pre-training score was 7.43 out of 15 (49.5\%); whereas the post-training average score was 13.13 out of $15(87.5 \%)$. 
Table 8

Knowledge Scores (percentage correct) Within Subjects (A) and Between Subjects (B)

\begin{tabular}{lrrrrr}
\hline & SS & DF & MS & F & Significance \\
\hline Pre/Post training (A) & 37684.46 & 1 & 37684.46 & 187.337 & $.000^{\star}$ \\
NS/S (B) & 1075.894 & 1 & 1075.894 & 3.447 & $.069 * \star$ \\
A x B & 10.919 & 1 & 10.919 & .054 & .817 \\
$\quad$ & & 59 & & & \\
\hline
\end{tabular}

Note. $\mathrm{NS}=$ non-symptomatic participants; $\mathrm{S}=$ symptomatic participants ${ }^{*} p<.01 ;{ }^{* *} p$ close to $<0.5$ and less than 0.1 demonstrates marginal significance

For both the pre-training assessment and the post-training assessment, the non-symptomatic group's mean score was lower than the symptomatic group's mean score (Table 9).

Table 9

Mean Knowledge Scores and Corresponding Percentage Correct

\begin{tabular}{lrrrr}
\hline & Non-symptomatic & Symptomatic $^{\mathrm{b}}$ & Total \\
\hline Pre-training & $6.36(42.38 \%)$ & $7.43(49.5 \%)$ & $6.84(45.62 \%)$ \\
Post-training & $12.25(81.67 \%)$ & $13.13(87.5 \%)$ & $12.65(84.31 \%)$ \\
\hline
\end{tabular}

Note. Mean score based on a total of 15 points possible.

${ }^{2} \mathrm{n}=28 ;{ }^{\mathrm{b}} \mathrm{n}=23$ 
The twenty-eight non-symptomatic participants' average pre-training assessment score was $6.36(42.38 \%)$ correct out of 15 ; whereas the symptomatic participants' mean score was $7.43(49.5 \%)$ out of 15 . The non-symptomatic participants' post-training assessment scores averaged $12.25(81.67 \%)$ correct out of 15 ; whereas the symptomatic participants' post-training assessment scores averaged $13.13(87.5 \%)$ correct out of 15 . 


\section{Chapter 5}

\section{DISCUSSION}

The provision of a 1-hour ergonomics training class to office workers did, unexpectedly, result in significant changes in attitude, perceived awareness, and knowledge regarding basic ergonomics guidelines and principles. In 1997, the ergonomics standard, California Code of Regulations (CCR), Section 5110: Repetitive Motions Injuries (RMI), passed into law. In 2001, Cal/OSHA Consultation addressed or recommended 337 ergonomics programs to employers (California Department of Industrial Relations, 2001). Publications and web sites regarding ergonomics are abundant and relatively accessible to the general public. It was expected that most workers would already have a basic understanding of ergonomic principles and guidelines. However, the outcome of this study indicates that the general working population still has a very limited understanding of basic ergonomics principles. This can be seen by the significant change in the participants' knowledge scores. Participants demonstrated minimal knowledge of basic office ergonomics before the training class. The 1-hour training class resulted in participants demonstrating a significant increase in knowledge. The mean total correct answers increased from $45.62 \%$ correct to $84.31 \%$ correct. The 15 multiple choice questions on the assessments such as "What is the guideline for the keyboard height?" were thought to reflect very basic office ergonomics principles. 
Understandably, along with their knowledge scores improving, their perceived awareness of ways to adjust the chair or workstation as well as work techniques significantly improved. Additionally, attitudes related to the belief that injury can be prevented by changing the way they work and their willingness to change the way they work also significantly increased.

The variable of musculoskeletal disorders did not have any significant interaction with attitude or awareness and was only marginally significant with knowledge. It is interesting to note that, although not statistically significant, employees reporting symptoms perceived themselves less aware, but scored higher (marginally significant) in knowledge compared to non-symptomatic employees. It would be interesting to explore this potential trend with a larger population and with a more detailed tool to measure awareness levels and knowledge. Do persons with discomfort have less confidence in their knowledge and yet have better basic understanding of ergonomics? If so, where and how are they getting the information?

The 1-hour training class included basic ergonomic guidelines for workstation adjustment and chair adjustment, as well as work technique. Participants' perceptions of their awareness of workstation and chair adjustment as well as work technique significantly improved with the 1 -hour training class. The need to include work technique in training is supported by Pascarelli (1999) who emphasizes that proper training will include ergonomics and biomechanics. He describes ergonomics as how the equipment fits the user, and biomechanics as how the user interacts with 
the equipment. Furthermore, Pascarelli states that technique training is even more important today because the inherent characteristics of the computer keyboard and its associated input devices all but encourage poor technique.

Twenty-eight of the participants reported no musculoskeletal disorders and the remaining 23 of the 51 participants reported having a musculoskeletal disorder, but had not filed a workers' compensation claim. This is consistent with other studies indicating that many work-related musculoskeletal disorders go unreported (Morse et al., 2001; Rosenmann et al., 2000, Silverstein et al., 1997). The reasons given in the other studies for non-reporting were described as the employees deemed the symptoms as too mild or transient, employees did not see the connection between the symptoms and their work, or the employees expressed concern about the reaction of the employers (Rosenmann et al., 2000; Silverstein et al., 1997). This study did not investigate the reasons for non-reporting. The cause as well as the cost of these unreported musculoskeletal disorders to employers warrants further investigation.

The general office workers appear to have limited understanding of basic ergonomics principles and guidelines. Ergonomics training that includes work technique as well as chair and workstation adjustment can be useful in improving attitude, awareness, and knowledge of general ergonomics principles and guidelines for employees with and without musculoskeletal symptoms. Therefore, ergonomics training is an essential part of a comprehensive ergonomics program. 


\section{REFERENCES}

Baldwin, T. T., \& Ford, J. K. (1988). Transfer of training: A review and directions for future research. Personnel Psychology, 41, 63-105.

Bohr, P. C. (2000). Efficacy of office ergonomics education. Journal of Occupational Rehabilitation, 10(4), 243-255.

Bureau of Labor Statistics. (2001). Retrieved March 10, 2005, from Bureau of Labor Statistics web site http://www.bls.gov/iif/oshwc/osh/case/ostb1154.pdf

Bureau of Labor Statistics. (2005). Definitions. Retrieved March 10, 2005, from Bureau of Labor Statistics web site http://www.bls.gov

California Commission on Health and Safety and Workers' Compensation [CHSWC]. (2003, August). Workers ' compensation medical care in California: System overview (Fact Sheet No. 1). San Francisco, CA: Author.

California Department of Industrial Relations [DIR]. (2000). Retrieved May 1, 2005, from DIR web site http://www.dir.ca.gov/dosh/doshreg/ergoconsultationactivities.pdf

California Department of Industrial Relations [DIR]. (2002). An employers' guide to workers' compensation in California (OSP Publication No. 00 36231). San Francisco: Author.

Christopher, W. D. (1992). Engineering psychology and human performance (2nd ed.). New York: Harper Collins.

DeFabio, R. (1995). Efficacy of comprehensive rehabilitation programs and back school for patients with low back pain: A meta-analysis. Physical Therapy, $75(10), 865-878$.

Ergonomics Society. (1996). Ergonomics. Retrieved April 4, 2003, from http://www.ergonomics.org.uk

Faucett, R., Garry, M., Nadler, D., \& Ettare, D. (2002). A test of two training interventions to prevent work-related musculoskeletal disorders of the upper extremity. Applied Ergonomics, 33, 337-347. 
Haines, H. M., Wilson, J. R., Vink, P., \& Kaningsveld, E. (2002). Variations and framework for participatory ergonomics. Ergonomics, 45, 926-936.

Haslam, R. A. (2002). Targeting ergonomics interventions--learning from health promotion. Ergonomics, 33, 241-249.

Kroemer, K. H. E., \& Grandjean, E. (1997). Fitting the task to the human (5th ed. rev.). Philadelphia, PA: Taylor \& Francis.

Johnston, J. J., Cattledge, G. H., \& Collins, J. W. (1994). The efficacy of training for occupational injury control. Occupational Medicine, 9(2), 147-158.

LeClaire, R., Esdiale, J. M., Suissa, S., Rossignol, M., Proulx, R., \& Dupuis, M. (1996). Back school in a first episode of compensated acute low back pain: A clinical trial to assess efficacy and prevent relapse. Archives of Physical Medicine and Rehabilitation, 77, 673-679.

Lindell, M. K. (1994). Motivational and organizational factors affecting implementation of worker safety training. Occupational Medicine: State of the Art Reviews, 9(2), 211-240.

Loisel, P., Gosselin, L., Durand, M., Lemaire, J., Poitras, S., \& Abenhaim, L. (2000). Implementation of a participatory ergonomics program in the rehabilitation of workers suffering from subacute back pain. Applied Ergonomics, 32, 53-60.

McCunney, R. J. (2001). Health and productivity: A role for occupational health professionals. Journal of Occupational and Environmental Medicine. Retrieved April 30, 2005, from American College of Occupational and Environmental Medicine web site http://www.acoem.org/health productivity/RoleOfOccHealth.asp

Menozzi, M., Boul, A. V., Waldmann, H., Kundig, S., Krueger, H., \& Spieler, W. (1999). Training in ergonomics at VDU workplaces. Ergonomics, 42(6), 835-845.

Merriam-Webster. (2002). Merriam-Webster dictionary online. Retrieved April 19, 2003, from http://www.m-w.com

Morse, T., Dillon, C., Warren, N., Hall, C., \& Hovey, D. (2001). Capture-recapture estimation of unreported work-related musculoskeletal disorders in Connecticut. American Journal of Industrial Medicine, 39(6), 636-642. 
Morse, T. F., Dillon, C., Warren, N., Levenstein, C., \& Warren, A. (1998). The economic and social consequences of work-related musculoskeletal disorders: The Connecticut upper-extremity surveillance project. International Journal of Occupational and Environmental Health, 4(4), 209-216.

National Institute for Occupational and Safety Health [NIOSH]. (1997a). Elements of ergonomics programs: A primer based on workplace evaluations and musculoskeletal disorders (NIOSH Publication No. 97-117). Cincinnati, OH: U.S. Department of Health and Human Services.

National Institute for Occupational and Safety Health [NIOSH]. (1997b). Musculoskeletal disorders and workplace factors: A critical review of epidemiological evidence for work-related musculoskeletal disorders of the neck, upper extremity, and low back (NIOSH Publication No. 97-141). Cincinnati, OH: U.S. Department of Health and Human Services.

Pascarelli, E. F. (1999). Training and retraining of office workers and musicians. Occupational Medicine: State of the Art Reviews, 14(1), 163-172.

Putz-Anderson, V. (Ed.). (1988). Cumulative trauma disorders: A manual for musculoskeletal diseases of the upper limbs. Cincinnati, OH: Taylor \& Francis.

Rankin, S. I., \& Stallings, K. D. (1996). Patient education issues, principles, practices (3rd ed.). Philadelphia: Lippincott.

Rosenmann, K. D., Gardiner, J. C., Wang, J., Biddle, J., Hogan, A., Reilly, M. J., Roberts, K., \& Welch, E. (2000). Why most workers with occupational repetitive trauma do not file for workers' compensation. Journal of Occupational and Environmental Medicine, 42(1), 25-34.

Schurman, S., Silverstein, B., \& Richards, S. (1994). Designing a curriculum for health workers: Reflections on the united automobile, aerospace and agricultural implement workers--General Motors ergonomics pilot project. Occupational Medicine, 9(2), 283-319.

Silverstein, B. A., Stetson, D. S., Keyserling, W. M., \& Fine, L. J. (1997). Work-related musculoskeletal disorders: Comparison of data sources for surveillance. American Journal of Industrial Medicine, 31(5), 600-608.

Stahl, C. (1997, April 28). On-site industrial rehabilitation. Advance for Occupational Therapists, 9, 13. 
Townsend, J. J. (1998). Ergonomics at the PC: Raising employee comfort levels through training. Professional Safety, 43(12), 20-23.

Urlings, I. J. M., Nijboer, I. D., \& Dul, J. (1990). A method for changing the attitudes and behavior of management and employees to stimulate the implementation of ergonomic improvement. Ergonomics, 33, 629-637.

Versloot, J. M., Rozeman, A., Van Soon, A. M., \& Van Akkerveeken, P. F. (1992). The cost-effectiveness of a back school program in industry: A longitudinal controlled field study. Spine, 17, 22-27.

Wickens, C. D. (1992). Engineering psychology and human performance (2nd ed.). New York: Harper Collins.

World Health Organization [WHO]. (1999). Making a difference. Geneva: Author. Retrieved April 30, 2005, from http://www.who.int/whr/1999/en/ 


\section{APPENDLX A}

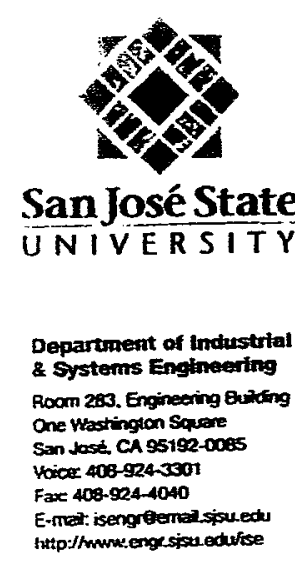

San José State

Departuent of industrial Cystors Englucering One Wastingion Squere San CA $95192-000$ trtp://muve:ergessiou edurise

\section{Consent Form}

\section{EAPLOYEES MGREEIENT TO PATICPATE N RESEARCH}

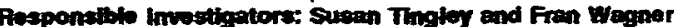

Thile of Protocol: Ofilice of Ergonomice Training

1. You have been asted to perticipare in a reseanch study investigating awareness of ergonomics princtios and guidelines in the office work-setting

2. You will be asterd to:

a. Complete a pro-training assossmen.

b. Paticipate in a 1-1/2 hour office ergonomics lecture style training chess. You wit recoive training handouts.

c. Complete a post traing assessment.

d. Complete a dornographic survey.

3. No safety rists are enticipatod You are encouraged to stand or change postion as noeded for comfort curing the training chass.

4. You may benefit from this research project by receining training and increasting awareness of ergonomics principles.

5. Although the resuls of this study may be published, no information thet could identify you will be included.

6. There is no compensation for your participation in this study.

7. Questions about this research may be addressed to:

$\begin{array}{ll}\text { Susan Tingloy, PT, CAE } & \text { Fran Wagner, MS, CIE } \\ \text { PO Box 2277 } & \text { PO Box 60268 } \\ \text { Granite Bay, CA 95746 } & \text { Sacramento, CA 85860-0268 } \\ \text { (916) 7840321 } & \text { (916) 482-5741 }\end{array}$

a. Complaints about the research may be presented to:

Kevin Corker, HFE Depertment Director

Inctustrial \& Systems Engineering Depertment

San Jose State University

One Washington Square

San Jose, CA 95192

(408) 9243988 Konincoder Osisuled

Ouestions about research stbjocts rights or research-related initry may be presented to:

Panola Stacks, PhD Interim Associate Vice Presidert

Graduate Studies and Roserch (403) 9247020

9. No service of any kind, to which you are otherwise entitad, will be lose or jecperdized if you choose to "not participate" in the study.

10. Your consent is being given voluntarity. You may refuse to perticipete in the ertire study or in any part of the study. F you decide to participete in the study, you are tree to withdraw at any time without any negative effiect on your relations with San Jose State thiversity or with any other participating institutions or agencies.

11. At the time that you sign this consent form, you wit receive a cepy of a for your records. signed and dated by the imestigator.

- The signature of a subject on this document indicates agreement to participate in the study.

口. The signature of a reseercher on this document indicates agreernert to inctude the above named subject in the research and attestation thex the subject has been fully informed of his or her rights.

\begin{tabular}{lll}
\hline & Signature & \\
\hline Susan Tangloy. PT. CAE & Signature & \\
\hline Fran Wagner, MS. CIE & Signature & Date
\end{tabular}




\section{APPENDIX B}

\section{Training Handout}
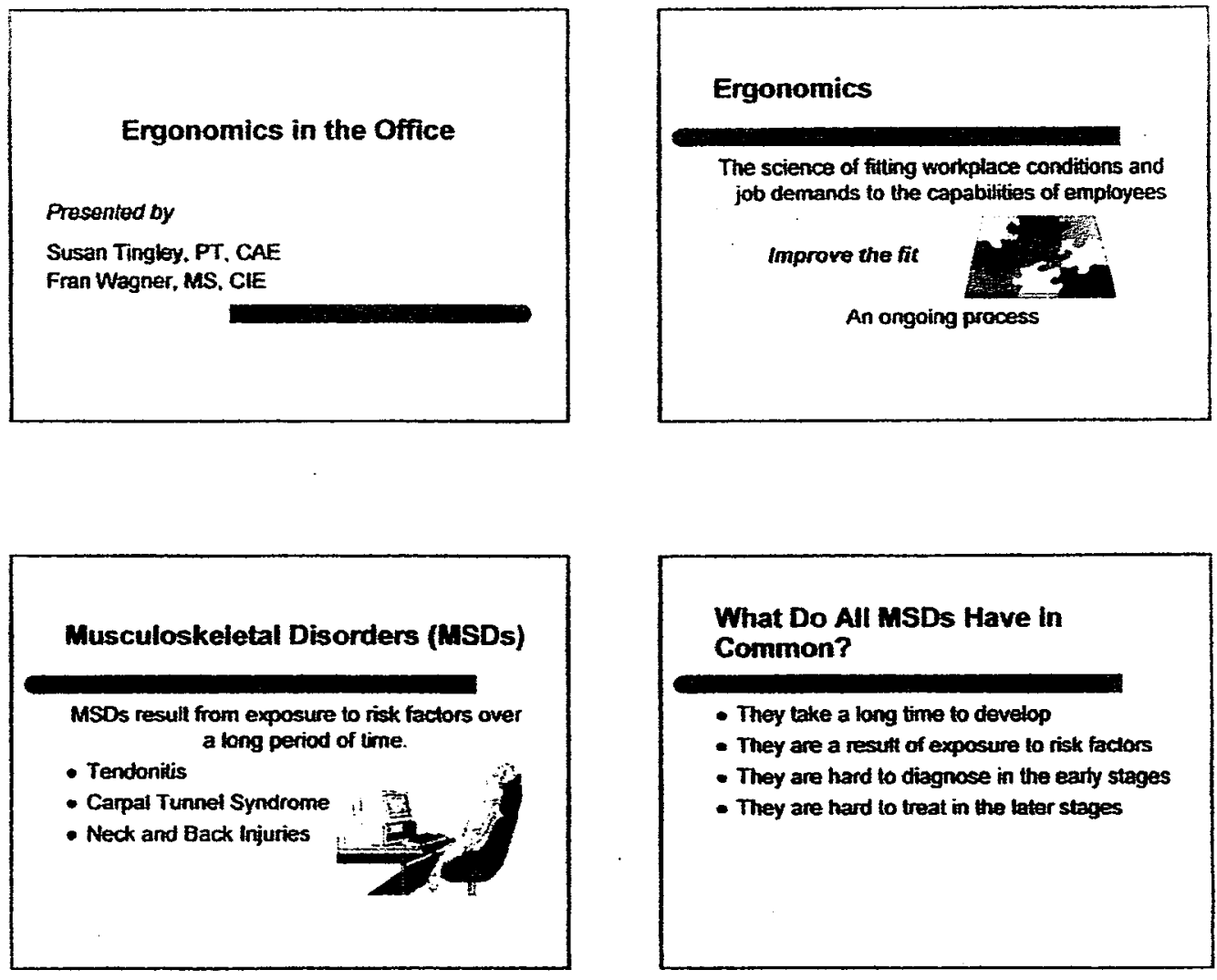

What Do All MSDs Have in Common?

- They take a long time to develop

- They are a result of exposure to risk factors

- They are hard to diagnose in the early stages

- They are hard to treat in the later stages

\section{Risk Factors}

Risk factors are conditions or crrcumstances that increase the chances of developing an injury.

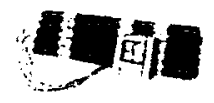

\section{Repetition}

- The same or similar movement

- Which is mare repelitive to use. the keytoard or the mouse?

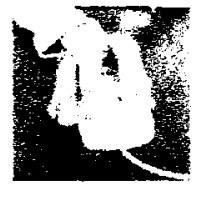




\section{How to reduce repetition}

- Use keyboard shortcut keys

- Aft key + underline letter opens the tool bar

- Sthit key + arrow key highlights across the tine

- Allernate right and left hand for the mouse

- Take minibreaks

- Use macros

\section{Force}

- The amount of physical effort lo do the job Pinch grip provides

$20 \%$

less strength than a power grip

- Large binders require

forceful pinch grip

- Break down large

binders

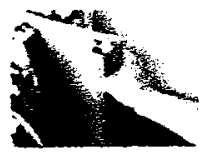

\section{Awkward Posture}

How to reduce force

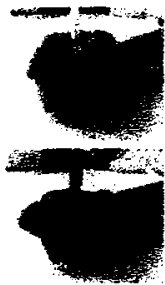

- Type fighty

Use large diameter

pens

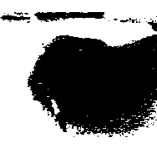

- A deviation from a mid-range position

- Keep your wists straight

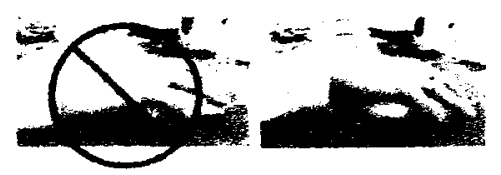

\section{Awkward Posture}

- Check your posture

- Adjust your workstation and equipment

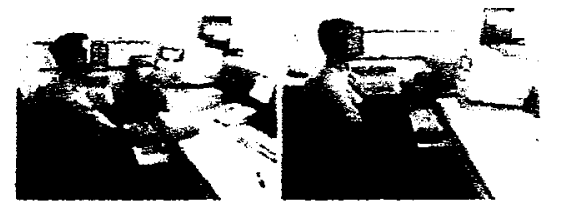



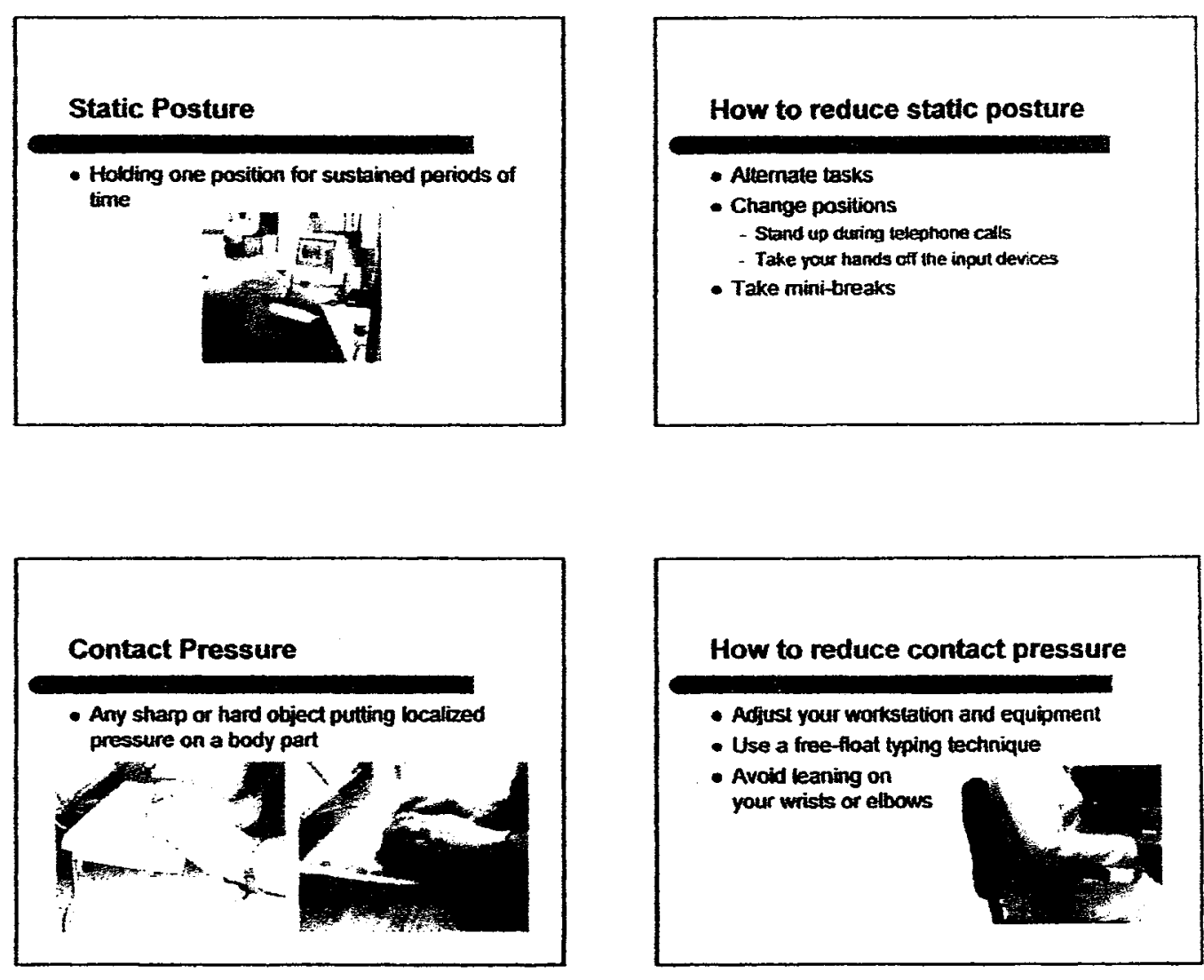

How to reduce contact pressure

- Adfust your workstation and equipment

- Use a free-float typing technique

- Avoid leaning on your wrists or elbows

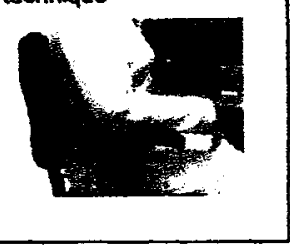

\section{Applying Ergonomics}

- Workstation Layout

- The chair

- Reach requirements

- Visual requirements

- Enviroment

- Habits \& Personal Preferences 

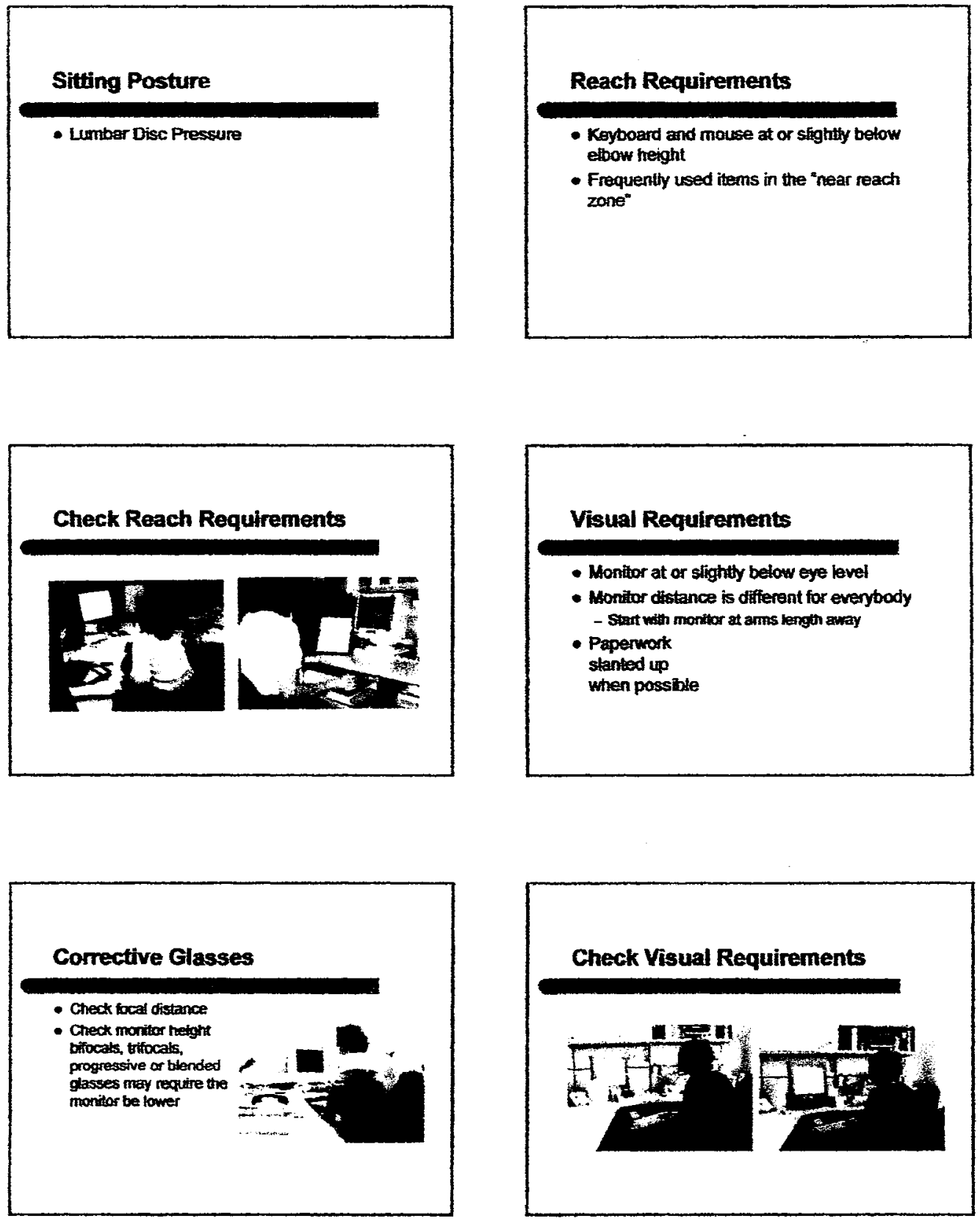

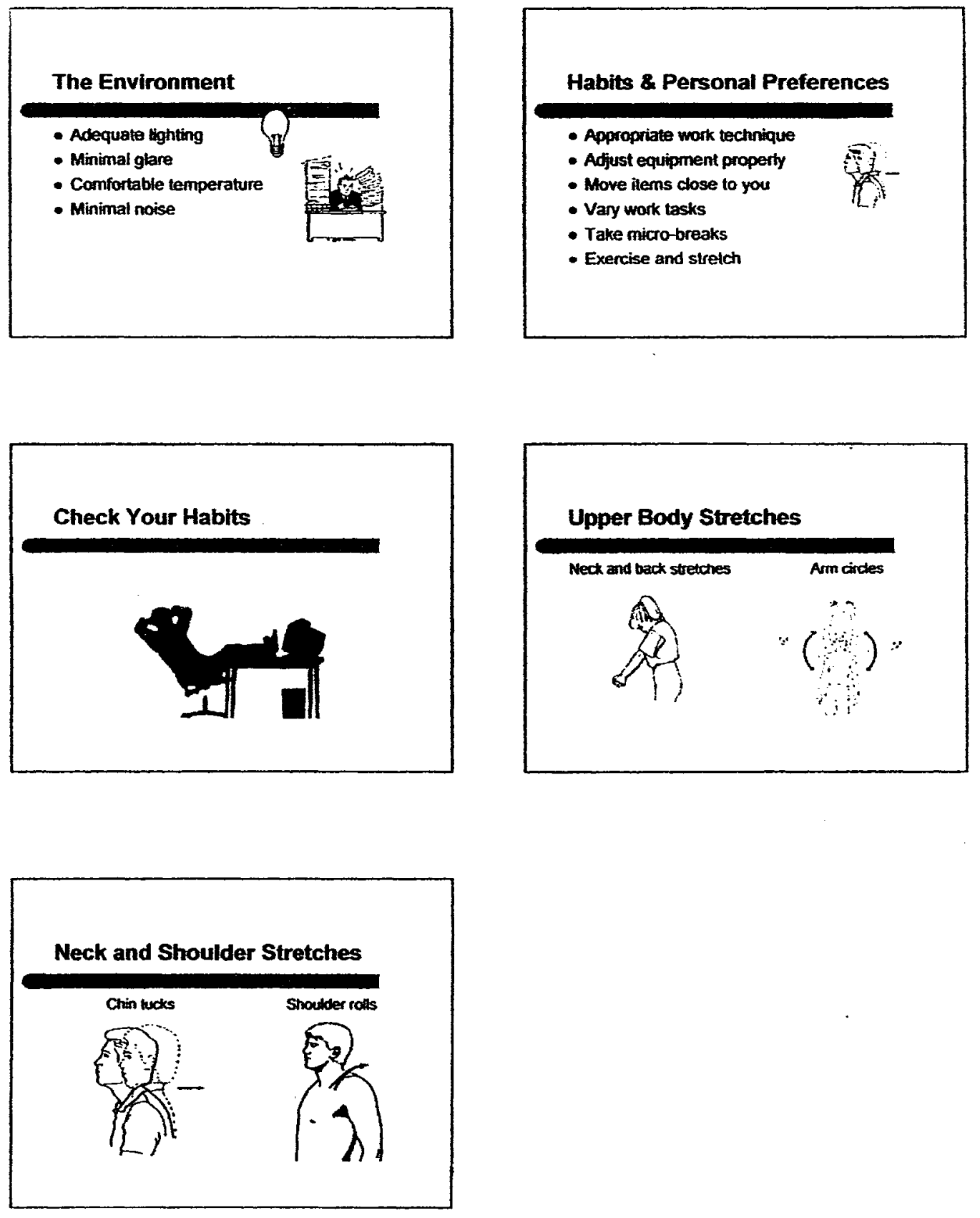


\section{APPENDIX C}

\section{Pre-Training Assessment}

\section{Write your ID number on each page of this assessment: $D \#$}

\section{Circle the answer that most closely matches your opinion}

1. Do you believe that you can prevent an injury by changing the way you work?

$$
\text { Yes No Maybe }
$$

2. Are you willing to change the way you work?

$$
\text { Yes No Maybe }
$$

3. Are you aware of ways to adjust your chair or workstation to make it safer? (circle only one number)

\begin{tabular}{|c|c|c|c|c|}
\hline Unaware & $\begin{array}{c}\text { Unaware of } \\
\text { most ways }\end{array}$ & $\begin{array}{c}\text { Somewhat } \\
\text { aware }\end{array}$ & $\begin{array}{c}\text { Aware of } \\
\text { most ways }\end{array}$ & Fully aware \\
\hline 1 & 2 & 3 & 4 & 5 \\
\hline
\end{tabular}

4. Are you aware of ways to change your work technique to make it safer? (circle only one number)

\begin{tabular}{|c|c|c|c|c|}
\hline Unaware & $\begin{array}{c}\text { Unaware of } \\
\text { most ways }\end{array}$ & $\begin{array}{c}\text { Somewhat } \\
\text { aware }\end{array}$ & $\begin{array}{c}\text { Aware of } \\
\text { most ways }\end{array}$ & Fully aware \\
\hline 1 & 2 & 3 & 4 & 5 \\
\hline
\end{tabular}

5. Is there anything you have already done or that you will do to your chair, workstation, or work techniques to make it safer? If so, please briefly list below. 
Read each question below. Then, select the BEST response from the choices to the right of each question. Select only one rexponse for each quextion. Print your response in the box to the right.

\begin{tabular}{|c|c|c|}
\hline $\begin{array}{l}\text { EXAMPLE: } \\
\text { Read the question below: }\end{array}$ & $\begin{array}{l}\text { Select the BEST answer. } \\
\text { Select only one response for each question: }\end{array}$ & $\begin{array}{l}\text { Record } \\
\text { Your } \\
\text { Answer }\end{array}$ \\
\hline $\begin{array}{l}\text { What does ergonomics } \\
\text { do for you? }\end{array}$ & $\begin{array}{l}\text { a) Reduces my risk for injury } \\
\text { b) Heips me understand my job tasks } \\
\text { c) Reduces my risk for heart disease } \\
\text { d) I don't know }\end{array}$ & A \\
\hline
\end{tabular}

\begin{tabular}{|l|l|l|}
\hline Read the questions below: & $\begin{array}{l}\text { Select the BEST answer. } \\
\text { Select only one response for each question: }\end{array}$ & $\begin{array}{l}\text { Record } \\
\text { Your } \\
\text { Answer }\end{array}$ \\
\hline
\end{tabular}

\begin{tabular}{|l|l|l|l|l|}
\hline 1 & $\begin{array}{l}\text { What are common signs } \\
\text { and symptoms of MSDs? }\end{array}$ & $\begin{array}{l}\text { a) } \\
\text { b) Infection and fever } \\
\text { c) Pain and swelling } \\
\text { d) I don't know }\end{array}$ & \\
\hline
\end{tabular}

\begin{tabular}{|l|l|l|l|}
\hline 2 & $\begin{array}{l}\text { What are some of the } \\
\text { work-related risk factors } \\
\text { that we know can cause } \\
\text { or contribute to work- } \\
\text { related musculoskeletal } \\
\text { disorders (MSDs)? }\end{array}$ & $\begin{array}{l}\text { a) Age, gender and heredity } \\
\text { b) Force, static posture, contact pressure, } \\
\text { vibration, temperature extremes and job } \\
\text { pressures }\end{array}$ \\
c) $\begin{array}{l}\text { Smoking, poor nutrition, pre-existing medical } \\
\text { conditions } \\
\text { I don't know }\end{array}$
\end{tabular}

\begin{tabular}{|l|l|l|l|}
\hline 3 & How can you reduce & a) Use the mouse more and the keyboard less \\
& repetitive hand motions & $\begin{array}{l}\text { b) Use the keyboard more and the mouse less } \\
\text { c) Handwrite notes first, then type them into the }\end{array}$ & $\begin{array}{l}\text { computer later } \\
\text { d) I don't know }\end{array}$
\end{tabular}

\begin{tabular}{|c|c|c|}
\hline 4 & $\begin{array}{l}\text { How can you reduce } \\
\text { awkward hand motions }\end{array}$ & $\begin{array}{l}\text { a) Move your hand more forward onto the mouse } \\
\text { b) Place only your fingertips on the mouse, keep } \\
\text { the heel of your hand on the work surface } \\
\text { c) Use a "windshield wiper" motion with your } \\
\text { wrist to move the mouse } \\
\text { d) I don't know }\end{array}$ \\
\hline
\end{tabular}




\begin{tabular}{|l|l|l|}
\hline Read the questions below: & $\begin{array}{l}\text { Select the BEST answer. } \\
\text { Select only one response for each question: }\end{array}$ & $\begin{array}{l}\text { Record } \\
\text { Your } \\
\text { Answer }\end{array}$ \\
\hline
\end{tabular}

\begin{tabular}{|l|l|l|l|}
\hline 5 & $\begin{array}{l}\text { What is the guideline of } \\
\text { the backrest to be at the } \\
\text { correct height to fit you? }\end{array}$ & $\begin{array}{l}\text { a) The curve of the backrest is slightly higher than } \\
\text { the deepest curve in my back } \\
\text { b) The curve of the backrest is slightly lower than } \\
\text { the deepest curve in my back } \\
\text { c) The curve of the chair back fits snugly into the } \\
\text { deepest curve in my back } \\
\text { d) I don't know }\end{array}$ \\
\hline
\end{tabular}

\begin{tabular}{|l|l|l|l|}
\hline 6 & $\begin{array}{l}\text { When the seat height of } \\
\text { the chair is correct, how } \\
\text { high is the seat compared } \\
\text { to your standing knee } \\
\text { height? }\end{array}$ & $\begin{array}{l}\text { a) The seat is at or slightly below my knees } \\
\text { b) The seat is } 3 \text { inches or more higher than my } \\
\text { knees } \\
\text { c) The seat is 3 inches or more below the height } \\
\text { of my knees } \\
\text { d) I don't know }\end{array}$
\end{tabular}

\begin{tabular}{|l|l|l|l|}
\hline 7 & $\begin{array}{l}\text { For people with low back } \\
\text { pain, what seated posture } \\
\text { is generally more } \\
\text { comfortable? }\end{array}$ & $\begin{array}{l}\text { a) Sitting upright (90 degrees) } \\
\text { b) Sitting slightly forward } \\
\text { c) Sitting slightly reclined } \\
\text { d) I don't know }\end{array}$ & \\
\hline
\end{tabular}

\begin{tabular}{|l|l|l|l|}
\hline 8 & $\begin{array}{l}\text { What is the guideline for } \\
\text { using the armrests on the } \\
\text { chair: }\end{array}$ & $\begin{array}{l}\text { a) } \text { My arms should rest on the arm rests only } \\
\text { while keying } \\
\text { b) My arms should rest on the armrests only } \\
\text { between keying activities } \\
\text { c) My arms should always be on the armrests } \\
\text { d) I don't know }\end{array}$
\end{tabular} \mid

\begin{tabular}{|l|l|l|l|}
\hline 9 & $\begin{array}{l}\text { What is the guideline } \\
\text { for keyboard height? }\end{array}$ & $\begin{array}{l}\text { a) It should be slightly higher than my elbows } \\
\text { b) It should be at or slightly below my elbows } \\
\text { c) It should be 29- 30" above the floor } \\
\text { d) I don't know }\end{array}$ & \\
\hline
\end{tabular}

\begin{tabular}{|l|l|l|l|}
\hline 10 & $\begin{array}{l}\text { If you are using the } \\
\text { mouse frequently while } \\
\text { keying, where should } \\
\text { the mouse be placed? }\end{array}$ & $\begin{array}{l}\text { a) The mouse should be as close to the keyboard as } \\
\text { possible, in the near reach zone } \\
\text { The mouse should at least an arm's length away, } \\
\text { in the mid reach zone } \\
\text { c) The distance of the mouse is not important. } \\
\text { d) I don't know }\end{array}$
\end{tabular} \mid




\begin{tabular}{|l|l|l|l|}
\hline Read the questions below: & $\begin{array}{l}\text { Select the BEST answer. } \\
\text { Select only one response for each question: }\end{array}$ & $\begin{array}{l}\text { Record } \\
\text { your } \\
\text { answer }\end{array}$ \\
\hline 11 & $\begin{array}{l}\text { When keying, what is the } \\
\text { guideline for wrist } \\
\text { posture? }\end{array}$ & $\begin{array}{l}\text { You should rest your wrists on the wrist } \\
\text { rest while keying } \\
\text { y) You should lift your wrists off the wrist } \\
\text { rest and keep your wrist straight (flat) } \\
\text { while keying } \\
\text { c) You should lift your wrists off the wrist } \\
\text { rest and bend (flex) at the wrist while } \\
\text { keying }\end{array}$ & \\
& d) I don't know & \\
\hline
\end{tabular}

\begin{tabular}{|l|l|l|l|}
\hline 12 & $\begin{array}{l}\text { When looking at the } \\
\text { monitor, what do you }\end{array}$ & $\begin{array}{l}\text { a) Raise the monitor a couple inches at a time } \\
\text { beed to do if you are }\end{array}$ & c) Nothing. This is the proper way to position \\
& $\begin{array}{l}\text { lifting your chin up and } \\
\text { tilting your head back to } \\
\text { see the top of the screen? }\end{array}$ & d) I don't know
\end{tabular} \mid

\begin{tabular}{|l|l|l|l|}
\hline 13 & $\begin{array}{l}\text { The monitor should } \\
\text { never be more than an } \\
\text { arm's length away from } \\
\text { your eyes. }\end{array}$ & $\begin{array}{l}\text { a) True } \\
\text { b) False } \\
\text { c) I don't know }\end{array}$
\end{tabular}

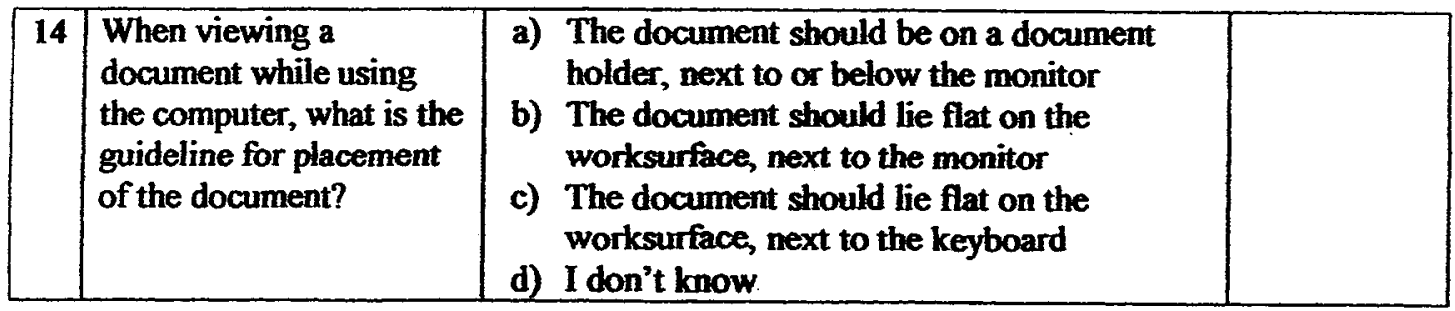

\begin{tabular}{|l|l|l|l|}
\hline 15 & $\begin{array}{l}\text { How can we be more } \\
\text { comfortable at our } \\
\text { computer workstations? }\end{array}$ & $\begin{array}{l}\text { a) We will be more comfortable at our } \\
\text { computers if all our workstations are set up } \\
\text { the same } \\
\text { b) We will be comfortable at our computers if } \\
\text { each workstation is set up for the individual } \\
\text { user }\end{array}$ \\
& c) We will be more comfortable at our \\
& $\begin{array}{l}\text { computers if we use more built-in furniture } \\
\text { "One size fits all". }\end{array}$ & d) I don't know
\end{tabular}


APPENDIX D

Post-Training Assessment

Write your ID number on each page of this assessment:

ID\#

\section{Circle the answer that most closely matches your opinion}

1. Do you believe that you can prevent an injury by changing the way you work?

$$
\text { Yes No Maybe }
$$

2. Are you willing to change the way you work?

$$
\text { Yes No Maybe }
$$

3. Are you aware of ways to adjust your chair or workstation to make it safer? (circle only one number)

\begin{tabular}{|c|c|c|c|c|}
\hline Unaware & $\begin{array}{c}\text { Unaware of } \\
\text { most ways }\end{array}$ & $\begin{array}{c}\text { Somewhat } \\
\text { aware }\end{array}$ & $\begin{array}{c}\text { Aware of } \\
\text { most ways }\end{array}$ & Fully aware \\
\hline 1 & 2 & 3 & 4 & 5 \\
\hline
\end{tabular}

4. Are you aware of ways to change your work technique to make it safer? (circle only one number)

\begin{tabular}{||c|c|c|c|c|}
\hline Unaware & $\begin{array}{c}\text { Unaware of } \\
\text { most ways }\end{array}$ & $\begin{array}{c}\text { Somewhat } \\
\text { aware }\end{array}$ & $\begin{array}{c}\text { Aware of } \\
\text { most ways }\end{array}$ & Fully aware \\
\hline 1 & 2 & 3 & 4 & 5 \\
\hline
\end{tabular}

5. Is there anything you have already done or that you will do to your chair, workstation, or work techniques to make it safer? If so, please briefly list below. 
Read each question below. Then, select the BEST response from the choices to the right of each question. Select only one response for each question. Print your response in the box to the right.

\begin{tabular}{|c|c|c|c|}
\hline \multicolumn{2}{|c|}{$\begin{array}{l}\text { EXAMPLE: } \\
\text { Read the question below: }\end{array}$} & $\begin{array}{l}\text { Select the BEST answer. } \\
\text { Select only one response for each question: }\end{array}$ & \multirow{2}{*}{$\begin{array}{l}\text { Record } \\
\text { Your } \\
\text { Answer } \\
\text { A }\end{array}$} \\
\hline & $\begin{array}{l}\text { What does ergonomics } \\
\text { do for you? }\end{array}$ & $\begin{array}{l}\text { e) Reduces my risk for injury } \\
\text { f) Helps me understand my job tasks } \\
\text { g) Reduces my risk for heart disease } \\
\text { h) I don't know }\end{array}$ & \\
\hline & d the questions below: & $\begin{array}{l}\text { Select the BEST answer. } \\
\text { Select only one response for each question: }\end{array}$ & $\begin{array}{l}\text { Record } \\
\text { Your } \\
\text { Answer }\end{array}$ \\
\hline 1 & $\begin{array}{l}\text { What are common signs } \\
\text { and symptoms of MSDs? }\end{array}$ & $\begin{array}{l}\text { e) Rash and itching } \\
\text { f) Infection and fever } \\
\text { g) Pain and swelling } \\
\text { h) I don't know }\end{array}$ & \\
\hline
\end{tabular}

\begin{tabular}{|c|l|}
\hline 2 & $\begin{array}{l}\text { What are some of the } \\
\text { work-related risk factors } \\
\text { that we know can cause } \\
\text { or contribute to work- } \\
\text { related musculoskeletal } \\
\text { disorders (MSDs)? }\end{array}$
\end{tabular}

e) Age, gender and heredity

f) Force, static posture, contact pressure, vibration, temperature extremes and job pressures

g) Smoking, poor nutrition, pre-existing medical conditions

h) I don't know

\begin{tabular}{|l|l}
\hline 3 & How can you reduce
\end{tabular} repetitive hand motions e) Use the mouse more and the keyboard less

f) Use the keyboard more and the mouse less

g) Handwrite notes first, then type them into the computer later

h) I don't know

\begin{tabular}{|c|l|}
\hline 4 & $\begin{array}{l}\text { How can you reduce } \\
\text { awkward hand motions }\end{array}$ \\
\hline
\end{tabular}

e) Move your hand more forward onto the mouse

f) Place only your fingertips on the mouse, keep the heel of your hand on the work surface

g) Use a "windshield wiper" motion with your wrist to move the mouse

h) I don't know 


\begin{tabular}{|l|l|l|}
\hline Read the questions below: & $\begin{array}{l}\text { Select the BEST answer. } \\
\text { Select only one response for each question: }\end{array}$ & $\begin{array}{l}\text { Record } \\
\text { Your } \\
\text { Answer }\end{array}$ \\
\hline
\end{tabular}

\begin{tabular}{|c|c|}
\hline $\begin{array}{l}\text { What is the guideline of } \\
\text { the backrest to be at the } \\
\text { correct height to fit you? }\end{array}$ & $\begin{array}{l}\text { e) The curve of the backrest is slightly higher than } \\
\text { the deepest curve in my back } \\
\text { f) The curve of the backrest is slightly lower than } \\
\text { the deepest curve in my back } \\
\text { g) The curve of the chair back fits snugly into the } \\
\text { deepest curve in my back } \\
\text { h) I don't know }\end{array}$ \\
\hline
\end{tabular}

\begin{tabular}{|l|l}
\hline 6 & When the seat height of
\end{tabular} the chair is correct, how high is the seat compared to your standing knee height?
e) The seat is at or slightly below my knees
f) The seat is 3 inches or more higher than my knees
g) The seat is 3 inches or more below the height of my knees
h) I don't know
e) Sitting upright (90 degrees)
f) Sitting slightly forward
g) Sitting slightly reclined
h) I don't know pain, what seated posture is generally more comfortable?

\begin{tabular}{|l|l|l|l|}
\hline 8 & $\begin{array}{l}\text { What is the guideline for } \\
\text { using the armrests on the } \\
\text { chair: }\end{array}$ & $\begin{array}{l}\text { e) My arms should rest on the arm rests only } \\
\text { while keying } \\
\text { f) My arms should rest on the armrests only } \\
\text { between keying activities } \\
\text { g) My arms should always be on the armrests } \\
\text { h) I don't know }\end{array}$
\end{tabular} \mid

9 What is the guideline for keyboard height? e) It should be slightly higher than my elbows

f) It should be at or slightly below my elbows

g) It should be 29-30" above the floor

h) I don't know

\begin{tabular}{|l|l|l|l|l|}
\hline 10 & $\begin{array}{l}\text { If you are using the } \\
\text { mouse frequently while } \\
\text { keying, where should } \\
\text { the mouse be placed? }\end{array}$ & $\begin{array}{l}\text { e) The mouse should be as close to the keyboard as } \\
\text { possible, in the near reach zone } \\
\text { The mouse should at least an arm's length away, } \\
\text { in the mid reach zone } \\
\text { g) The distance of the mouse is not important } \\
\text { h) I don't know }\end{array}$ & \\
\hline
\end{tabular}




\begin{tabular}{|c|c|c|c|}
\hline \multicolumn{2}{|c|}{ Read the questions below: } & $\begin{array}{l}\text { Select the BEST answer. } \\
\text { Select only one response for each question: }\end{array}$ & \multirow[t]{2}{*}{$\begin{array}{l}\text { Record } \\
\text { your } \\
\text { answer } \\
\end{array}$} \\
\hline 11 & $\begin{array}{l}\text { When keying, what is the } \\
\text { guideline for wrist } \\
\text { posture? }\end{array}$ & $\begin{array}{l}\text { e) You should rest your wrists on the wrist } \\
\text { rest while keying } \\
\text { f) You should lift your wrists off the wrist } \\
\text { rest and keep your wrist straight (flat) } \\
\text { while keying } \\
\text { g) You should lift your wrists off the wrist } \\
\text { rest and bend (flex) at the wrist while } \\
\text { keying } \\
\text { h) I don't know }\end{array}$ & \\
\hline 12 & $\begin{array}{l}\text { When looking at the } \\
\text { monitor, what do you } \\
\text { need to do if you are } \\
\text { lifting your chin up and } \\
\text { tilting your head back to } \\
\text { see the top of the screen? }\end{array}$ & $\begin{array}{l}\text { e) Raise the monitor a couple inches at a time } \\
\text { f) Raise the chair or lower the monitor } \\
\text { g) Nothing. This is the proper way to position } \\
\text { the monitor. } \\
\text { h) I don't know }\end{array}$ & \\
\hline 13 & $\begin{array}{l}\text { The monitor should } \\
\text { never be more than an } \\
\text { arm's length away from } \\
\text { your eyes. }\end{array}$ & $\begin{array}{l}\text { d) True } \\
\text { e) False } \\
\text { f) I don't know }\end{array}$ & \\
\hline
\end{tabular}

\begin{tabular}{|l|l|l|l|}
\hline 14 & $\begin{array}{l}\text { When viewing a } \\
\text { document while using } \\
\text { the computer, what is the } \\
\text { guideline for placement } \\
\text { of the document? }\end{array}$ & $\begin{array}{l}\text { e) } \begin{array}{l}\text { The document should be on a document } \\
\text { holder, next to or below the monitor } \\
\text { The document should lie flat on the } \\
\text { worksurface, next to the monitor } \\
\text { g) }\end{array} \\
\begin{array}{l}\text { The document should lie flat on the } \\
\text { worksurface, next to the keyboard } \\
\text { I don't know }\end{array}\end{array}$ & \\
\hline
\end{tabular}

\begin{tabular}{|l|l|l|l|}
\hline 15 & $\begin{array}{l}\text { How can we be more } \\
\text { comfortable at our } \\
\text { computer workstations? }\end{array}$ & $\begin{array}{l}\text { e) } \begin{array}{l}\text { We will be more comfortable at our } \\
\text { computers if all our workstations are set up } \\
\text { the same } \\
\text { We will be comfortable at our computers if } \\
\end{array} \\
\text { each workstation is set up for the individual } \\
\text { user } \\
\text { g) We will be more comfortable at our } \\
\text { computers if we use more built-in furniture } \\
\text { "One size fits all". } \\
\text { h) I don't know }\end{array}$ \\
\hline
\end{tabular}




\section{APPENDIX E}

\section{Demographic Survey}

ID \#

1. What is your age?

2. Gender? Male Female

3. Have you ever had a work-related musculoskeletal disorder (MSD)? No Yes

4. Did you file a Workers' Compensation claim for your MSD? No Yes

5. Where was your injury? (Check all that apply).

\begin{tabular}{|l|l|}
\hline \multicolumn{1}{|c|}{ Area } & $\checkmark$ \\
\hline Neck & \\
\hline Shoulder(s) & \\
\hline Elbow(s) & \\
\hline Wrist/hand(s) & \\
\hline Upper back & \\
\hline Midback & \\
\hline Low back & \\
\hline Hip(s) & \\
\hline Leg(s) & \\
\hline Ankle(s) & \\
\hline Feet & \\
\hline Other: & \\
\hline
\end{tabular}

6. Have you received ergonomics training before? No Yes

7. Who provided the training?

Medical provider Employer Other:

8. What type of training was provided?

Written material

Lecture/classroom/one-on-one training Internet

Other: 